\title{
Effect of Different Herbicides on the Mycelial Growth of Rhizoctonia solani in vitro
}

\author{
Y. Sandhya ${ }^{1^{*}}$, C.P.D. Rajan ${ }^{2}$ and M. Reddi Kumar ${ }^{3}$ \\ ${ }^{1,3}$ Department of Plant pathology, S.V. Agricultural College, Tirupati, \\ Chittoor (Dt) PIN: 517 502, India \\ ${ }^{2}$ Agricultural Research Station, Nellore (Pin:524003), A.P., India \\ *Corresponding author
}

\section{A B S T R A C T}

\section{Keywords}

Sheath blight,

Sclerotia,

Rhizoctonia solani

Article Info

Accepted:

06 June 2018

Available Online:

10 July 2018
Rice sheath blight pathogen Rhizoctonia solani was isolated from the diseased samples obtained from Agricultural Research Station, Nellore. Pathogenicity of $R$. solani on rice leaves was assessed following detached leaf technique. The herbicides viz., Glyphosate, 2,4-D Sodium salt, Butachlor, Pretilachlor, Oxadiargyl, Pyrazosulfuron ethyl, Bensulfuron methyl $0.6 \%$ + Pretilachlor 6\%, Cyhalofop-butyl, Bispyribac sodium and Ethoxy sulfuron were tested at recommended concentrations by poisoned food technique were significantly superior over control in checking the mycelial growth of $R$. solani. Glyphosate, Butachlor, Pretilachlor showed 100 per cent inhibition.

\section{Introduction}

The pathogen is known to cause the damage at different stages viz., seed germination, seedling establishment and vegetative growth phase. As a result, productivity and quality of grains and seeds are reduced considerably. Besides the disease management, practice through cultural methods, chemical control, is the net promising method. Herbicides also have shown to increase or decrease some plant diseases especially those caused by soil borne pathogens (Kathan and Eshel, 1973; Papavizas and Lewis, 1979). There was decrease in the mycelial growth of $R$. solani by the herbicide Paraquat (Pathak et al., 1996). As an interesting nontarget effect, the biological activity of herbicides extends beyond their effect on target organisms and herbicides may influence plant-pathogen interactions through their effect on the pathogen, the plant, or on the surrounding soil organisms including symbiotic interactions.

Hence, in the present study herbicides were used to evaluate their efficacy in controlling sheath blight. 


\section{Materials and Methods}

The present experiments were carried out in the Department of Plant Pathology, S.V. Agricultural College, Tirupati, and Agricultural Research Station, Nellore, of Acharya N.G. Ranga Agricultural University, Guntur, Andhra Pradesh. The test pathogen $R$. solani was isolated from sclerotial bodies attached to the diseased portion of rice plants.

\section{Proving pathogenecity of the pathogen $R$. solani by Detached Leaf Technique}

Rice cv NLR34449 was sown in the pots under greenhouse conditions. When the seedlings were of Forty days old, the leaves were detached from the plants, cut in to $6 \mathrm{~cm}$ segments, surface sterilized with $70 \%$ ethyl alcohol, washed 3-4 times with sterile distilled water and placed in the moist chamber. Two days old culture disc $(2 \mathrm{~mm})$ of $R$. solani was inoculated on the rice leaf segments. Control was maintained without inoculation. The cotton swabs dipped in sterile water were placed on both sides of leaf segments. The moist chamber was maintained. Observations were recorded on development of sheath blight lesions Figure 1.

Effect of different herbicides on the mycelial growth of $R$. solani in vitro

Effect of herbicides on mycelial growth of $R$. solani was tested by poisoned food technique (Nene and Thapliyal, 1986) by measuring the radial growth of the fungus. The list of herbicides with their concentrations used in the study is presented in the Table 1 .

\section{Poisoned food technique}

For each treatment, $30 \mathrm{ml}$ of double strength potato dextrose agar (PDA) medium was taken in $100 \mathrm{ml}$ conical flask and autoclaved. To this medium, specified herbicide concentration was dissolved in $30 \mathrm{ml}$ distilled water was added to the medium at lukewarm temperature and mixed thoroughly. The poisoned medium was equally distributed in three petriplates, which were treated as three replications and allowed to solidify. The test pathogen $R$. solani was cut into $5 \mathrm{~mm}$ discs from the periphery of actively growing colony with sterilized cork borer and transferred to the centre of the each plate containing poisoned medium. Control was maintained by placing fungal discs in plates containing untreated (non poisoned) medium. The inoculated petriplates were incubated at $28 \pm 2^{\circ} \mathrm{C}$ in BOD incubator. The radial growth of fungus in the treatments was measured when growth in the control plate attained maximum. Per cent inhibition of the radial growth was calculated using the following formula (Vincent et al., 1927).

$\mathrm{I}=\frac{\mathrm{C}-\mathrm{T}}{\mathrm{C}} \mathrm{X} 100$

Where,

$\mathrm{I}=$ Inhibition per centage,

$\mathrm{C}=$ Growth in Control $(\mathrm{cm})$

$\mathrm{T}=$ Growth in Treatment $(\mathrm{cm})$.

Per cent inhibition of the organism in different chemical treatments over the control was recorded.

\section{Results and Discussion}

Effect of different herbicides on the mycelial growth of $R$. solani in vitro

The effect of ten herbicides viz., Glyphosate, 2,4-D Sodium salt, Butachlor, Pretilachlor, Oxadiargyl, Pyrazosulfuron ethyl, Bensulfuron methyl $0.6 \%$ + Pretilachlor $6 \%$, Cyhalofop- butyl, Bispyribac sodium and Ethoxy sulfuron were tested on the mycelial growth of $R$. solani in vitro by following poisoned food technique and per cent growth inhibition was calculated. The data presented in Table 2 revealed that all the herbicides tested at recommended concentrations were 
significantly superior over control in checking the mycelial growth of the test pathogen (Graph1). However significant difference among the treatments was observed. Glyphosate, Butachlor, Pretilachlor showed $100 \%$ inhibition followed by Bispyribac sodium (89.27 \%), Cyhalofop - butyl (85.83 $\%)$, Bensulfuron methyl $0.6 \%$ + Pretilachlor $6 \%(84.90 \%), 2,4-D$ Sodium salt $(41.83 \%)$, Ethoxy sulfuron (31.63\%), Pyrazosulfuron ethyl $(24.20 \%)$ and Oxadiargyl (18.47\%)
(Fig.2 and 3). Pathak et al., (1996) observed the effect of herbicides on $R$. solani. Paraquat was most potent in reducing the mycelial growth followed by thiobencarb, Butachlor and 2,4-D. Similarly herbicide Pretilachlor belonging to same group as Butachlor has also been reported to suppress the growth of $R$. solani. The results of the present study on Glyphosate are in agreement with the work of Black et al., (1996).

Fig.1 Pathogenicity of $R$. solani by detached leaf technique

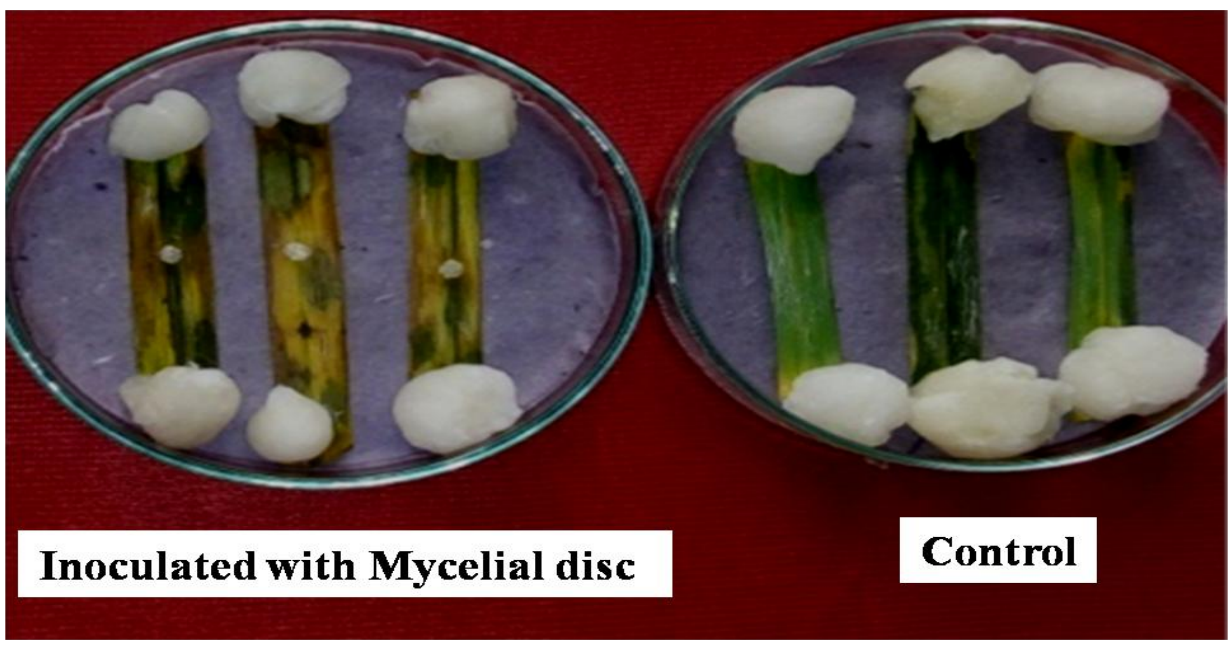

Fig.2 In vitro efficacy of herbicides on mycelial growth of $R$. solani by poisoned food technique

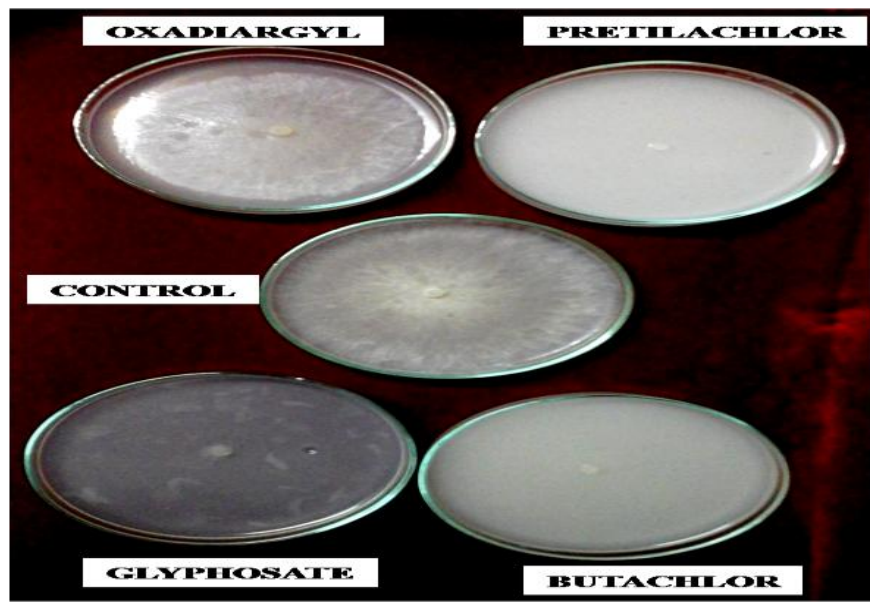


Table.1 List of the herbicides and their concentrations tested

\begin{tabular}{|c|l|c|}
\hline $\begin{array}{c}\text { TREATMENT } \\
\text { NUMBER }\end{array}$ & \multicolumn{1}{|c|}{ HERBICIDE } & DOSAGE \\
\hline 1 & Glyphosate 41SL & $10 \mathrm{ml} / 1$ \\
\hline 2 & 2,4-D Sodium Salt 80WP & $2 \mathrm{~g} / 1$ \\
\hline 3 & Butachlor 60EC & $6.25 \mathrm{ml} / 1$ \\
\hline 4 & Pretilachlor 50EC & $2.5 \mathrm{ml} / 1$ \\
\hline 5 & Oxadiargyl 80WP & $0.2 \mathrm{~g} / 1$ \\
\hline 6 & Pyrazosulfuron ethyl 75WDG & $20 \mathrm{~g} / 1$ \\
\hline 7 & $\begin{array}{l}\text { Bensulfuron methyl 0.6\% + } \\
\text { Pretilachlor 6\% GR (Londax) }\end{array}$ \\
\hline 8 & Cyhalofop- butyl 10EC & $2 \mathrm{ml} / 1$ \\
\hline 9 & Bispyribac- sodium 10SC & $0.6 \mathrm{ml} / 1$ \\
\hline 10 & Ethoxysulfuron 15WDG & $0.25 \mathrm{~g} / 1$ \\
\hline 11 & Untreated control & - \\
\hline
\end{tabular}

Graph.1 In vitro efficacy of herbicides on the mycelial growth of Rhizoctonia solani

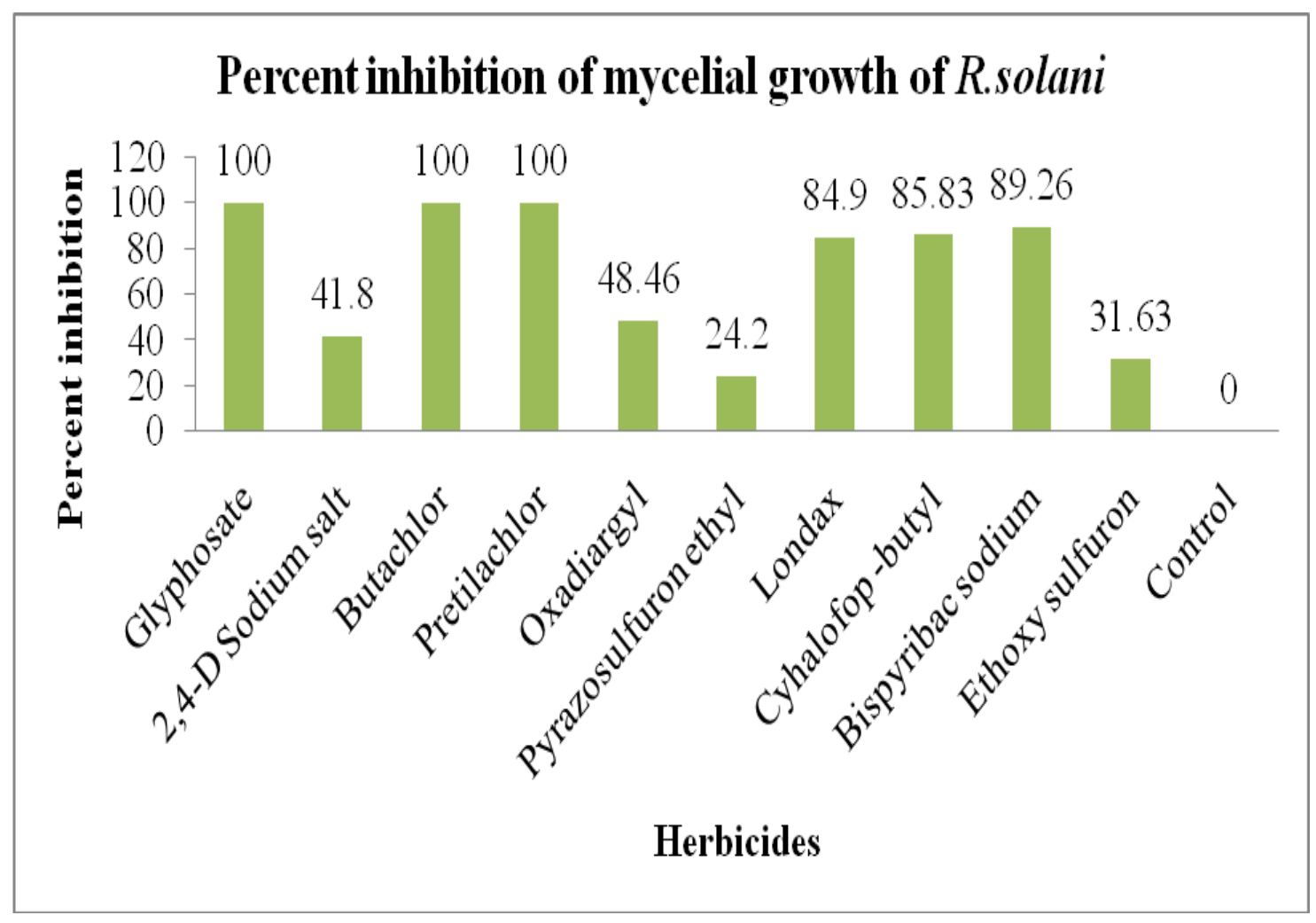


Table.2 In vitro evaluation of herbicides on the mycelial growth of Rhizoctonia solani

\begin{tabular}{|c|l|c|c|c|}
\hline S. No. & Herbicides & Concentration & $\begin{array}{c}\text { Radial growth } \\
(\mathrm{cm})\end{array}$ & Per cent Inhibition \\
\hline $\mathbf{1}$ & Glyphosate & $10.00 \mathrm{ml} / 1$ & 0.00 & $100.00(90.00)^{* *}$ \\
\hline $\mathbf{2}$ & 2,4-D Sodium salt & $2.00 \mathrm{~g} / 1$ & 2.60 & $41.83(40.28)$ \\
\hline $\mathbf{3}$ & Butachlor & $6.25 \mathrm{ml} / 1$ & 0.00 & $100.00(90.00)$ \\
\hline $\mathbf{4}$ & Pretilachlor & $2.50 \mathrm{ml} / 1$ & 0.00 & $100.00(90.00)$ \\
\hline $\mathbf{5}$ & Oxadiargyl & $0.20 \mathrm{~g} / 1$ & 3.66 & $18.47(25.43)$ \\
\hline $\mathbf{6}$ & Pyrazosulfuron ethyl & $4.00 \mathrm{~g} / 1$ & 3.41 & $84.20(29.45)$ \\
\hline $\mathbf{7}$ & Bensulfuronethyl 0.6\% & $20.00 \mathrm{~g} / 1$ & 0.68 & $85.10)$ \\
\hline $\mathbf{8}$ & + Pretilachlor 6\% & & & $83(67.87)$ \\
\hline $\mathbf{9}$ & Cyhalofop-butyl & $2.00 \mathrm{ml} / 1$ & 0.64 & $31.63(34.21)$ \\
\hline $\mathbf{1 0}$ & Bispyribac-sodium & $0.60 \mathrm{ml} / 1$ & 0.48 & $0.00(0.00)$ \\
\hline $\mathbf{1 1}$ & Ethoxysulfuron & $0.25 \mathrm{ml} / 1$ & 3.07 & 0.917 \\
\hline & Control & - & 4.50 & 0.311 \\
\hline & CD $(P=0.01)$ & & & 0.439 \\
\hline & SEm \pm & & & 0.978 \\
\hline
\end{tabular}

*Mean of three replications.

** Figures in parentheses are angular transformed values

Fig.3 In vitro efficacy of herbicides on mycelial growth of $R$. solani by poisoned food technique

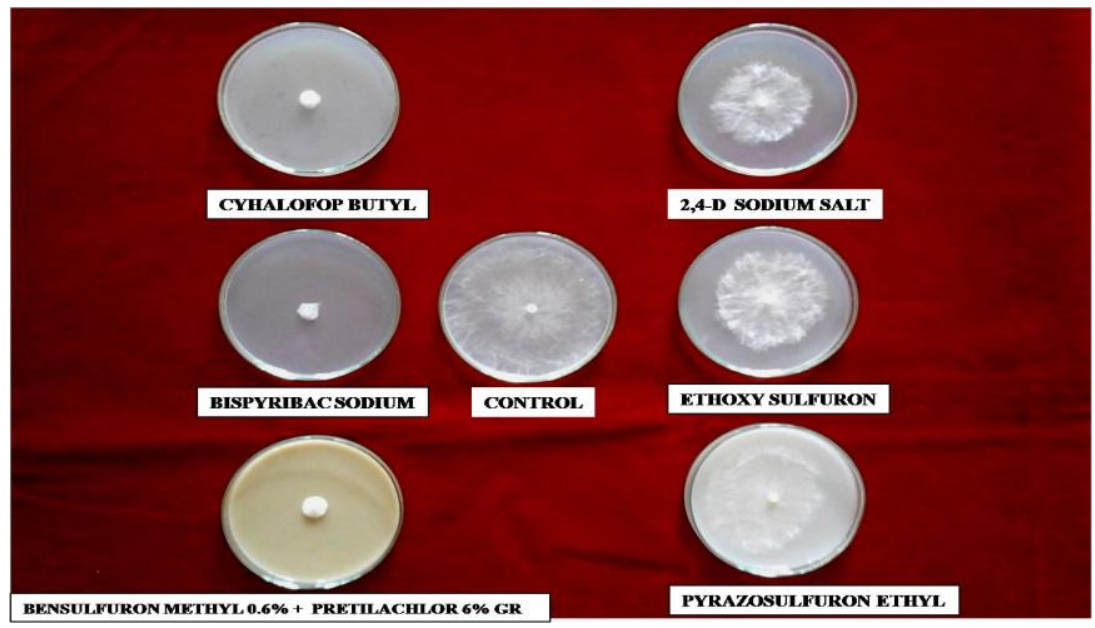




\section{Acknowledgements}

Financial support received from Acharya N.G. Ranga Agricultural University, Andhra Pradesh is great fully acknowledged. This work is the part of Thesis submitted to Acharya N.G. Ranga Agricultural University

\section{References}

Black DB, Russin JS, Griffin JL and Snow JP (1996). Herbicide effects on Rhizoctonia solani in vitro and Rhizoctonia foliar blight of soybean (Glycine max). Weed Science. 44: 711716.

Katan J and Eshel Y (1973). Interactions between herbicides and plant pathogens. Residue Reviews. 45: 145147.

Nene and Thapliyal (1986). Fungicides in Plant Disease Control. Oxford and IBH Publishing House, New Delhi. 163.

Papavizas GC and Lewis JA (1979). Influence of the herbicides EPTC and Prometryn on cotton Seedling disease caused by Thielaviopsis basicola. Canadian Journal Of Plant Pathology. 1: 100106.

Pathak D, Roy AK and Deka SC (1996). Effect of herbicides on the growth and sclerotial survival of Rhizoctonia solani Kuhn. Annuals of Biology. 12(2): 245-251.

\section{How to cite this article:}

Sandhya, Y., C.P.D. Rajan and Reddi Kumar, M. 2018. Effect of Different Herbicides on the Mycelial Growth of Rhizoctonia solani in vitro. Int.J.Curr.Microbiol.App.Sci. 7(07): 545-550. doi: https://doi.org/10.20546/ijcmas.2018.707.067 